\title{
Factors influencing the retention of an oral dose of radioactive manganese by the chick
}

\author{
BY J. W. MATHERS AND R. HILL \\ Royal Veterinary College, University of London \\ (Received ${ }_{3}$ fuly 1966-Accepted ${ }_{4}$ March г967)
}

\begin{abstract}
I. In two experiments, involving 1 10 chicks up to 5 weeks of age, retention of an oral dose of ${ }^{54} \mathrm{Mn}$ was always low; less than $5 \%$.

2. There were no significant differences in retention by hybrid broiler cocks, hybrid layer cocks, and hybrid layer pullets, nor was retention affected by the period of fasting, i.e. $I_{2}^{\frac{1}{2}}$ or $24 \mathrm{~h}$, before dosing.

3. Two-week-old birds retained $58 \%$ more radioactive manganese than 5 -week-old birds, and retention in birds killed $24 \mathrm{~h}$ after the dose was only $64 \%$ of that in birds killed $4 \mathrm{~h}$ after the dose.

4. With the addition to a fixed dose of ${ }^{54} \mathrm{Mn}$ of increasing quantities of non-radioactive $\mathrm{Mn}$ retention decreased only from $2.52 \%$ with no $\mathrm{Mn}$ added to $1.02 \%$ with $5000 \mu \mathrm{g} \mathrm{Mn}$ added, representing a very large increase in total retention of $\mathrm{Mn}$.
\end{abstract}

In an earlier study with adult birds the retention of an oral dose of ${ }^{54} \mathrm{Mn}$, as assessed by analyses of droppings, blood and liver, was consistently low (Hill, 1965). It was decided to determine the retention more accurately by analysis of the whole bird and the distribution of retained manganese between liver and the whole bird; this study is reported here, and the experiment began when the chicks were I day old. Another observation in the previous study, namely the relatively small effect on retention of ${ }^{54} \mathrm{Mn}$ of adding a large amount of inactive $\mathrm{Mn}$, was also investigated more closely. Furthermore, effects of sex, genetic make-up and time relationships between dosing and killing were studied.

\section{EXPERIMENTAL}

Expt I. Seventy-five day-old chicks-twenty-five hybrid layer pullets, twenty-five hybrid layer cockerels and twenty-five hybrid broiler cockerels-were fed from a day old on a low-Mn diet containing $4 \mu \mathrm{g} \mathrm{Mn} / \mathrm{g}$, and divided at random into the treatment groups shown in Table $\mathrm{I}$. The birds were given an oral dose of ${ }^{54} \mathrm{Mn}$ as the chloride, about $\mathrm{I} \cdot 5 \mu \mathrm{c}$ of carrier-free solution, and determinations of radioactivity in liver and remaining carcass, after discarding the contents of the digestive tract, were made as described in the previous paper (Hill, 1967 ). The quantities of ${ }^{54} \mathrm{Mn}$ in the liver and in the whole bird (liver plus carcass) were calculated as percentages of the dose.

Expt 2. Thirty-five hybrid layer pullets aged $4 \frac{1}{2}$ weeks that had been given a low-Mn diet $(5 \mu \mathrm{g} \mathrm{Mn} / \mathrm{g}$ ) were divided randomly into seven groups each of five birds. Each was dosed orally with $2 \mathrm{ml}$ of a solution containing about $2 \mu \mathrm{c}{ }^{54} \mathrm{Mn}$, as the chloride, and varying quantities of inactive $M n$ as the sulphate: $0,250,625,1250,1875,2500$ or $5000 \mu \mathrm{g} \mathrm{Mn}$. The solution of $2 \mu \mathrm{c}$ carrier-free ${ }^{54} \mathrm{Mn}$ contained $0 . \mathrm{I} \mu \mathrm{g}$ inactive $\mathrm{Mn}$. The addition of $25^{\circ} \mu \mathrm{g}$ non-radioactive Mn corresponds to the total daily Mn intake 
of a bird eating $25 \mathrm{~g}$ of a diet containing $10 \mu \mathrm{g} \mathrm{Mn} / \mathrm{g}$. Food was removed $\mathrm{I} \frac{1}{2} \mathrm{~h}$ before dosing and, $24 \mathrm{~h}$ afterwards, the birds were killed. Determinations of radioactivity in liver and remaining carcass (after removing the contents of the digestive tract) were determined as in Expt $\mathrm{I}$.

\begin{tabular}{|c|c|c|c|c|}
\hline Type of hybrid & $\begin{array}{l}\text { Age killed } \\
\text { (weeks) }\end{array}$ & $\begin{array}{c}\text { Time fasted before } \\
\text { dosing (h) }\end{array}$ & $\begin{array}{l}\text { Time after dosing } \\
\text { before killing }(\mathrm{h})\end{array}$ & $\begin{array}{l}\text { Group designations of } \\
\text { comparisons made } \\
\text { in Table } 2\end{array}$ \\
\hline Layer $+(25)$ & $\begin{array}{l}2(\mathrm{I} 4) \\
5(\mathrm{II})\end{array}$ & $\begin{array}{l}1 \cdot 5(7) \\
24(7) \\
1 \cdot 5 \\
I \cdot 5\end{array}$ & $\begin{array}{l}24 \\
24 \\
4(5) \\
24(6)\end{array}$ & $\begin{array}{l}\text { A, D, F } \\
\text { A, G } \\
\text { A, H } \\
\text { A, E, I }\end{array}$ \\
\hline Layer ${ }^{\star}(25)$ & $\begin{array}{l}2\left(I_{4}\right) \\
5(\mathrm{II})\end{array}$ & $\begin{array}{l}I \cdot 5(7) \\
24(7) \\
I \cdot 5 \\
I \cdot 5\end{array}$ & $\begin{array}{l}24 \\
24 \\
4(6) \\
24(5)\end{array}$ & $\begin{array}{l}\mathrm{B}, \mathrm{D}, \mathrm{F} \\
\mathrm{B}, \mathrm{G} \\
\mathrm{B}, \mathrm{H} \\
\mathrm{B}, \mathrm{E}, \mathrm{I}\end{array}$ \\
\hline Broiler o (25) & $\begin{array}{l}2(\mathrm{I} 4) \\
5(\mathrm{II})\end{array}$ & $\begin{array}{l}\mathbf{I} \cdot 5(7) \\
24(7) \\
I \cdot 5 \\
I \cdot 5\end{array}$ & $\begin{array}{l}24 \\
24 \\
4(5) \\
24(6)\end{array}$ & $\begin{array}{l}\mathrm{C}, \mathrm{D}, \mathrm{F} \\
\mathrm{C}, \mathrm{G} \\
\mathrm{C}, \mathrm{H} \\
\mathrm{C}, \mathrm{E}, \mathrm{I}\end{array}$ \\
\hline
\end{tabular}

Numbers of birds are given in parentheses.

\section{RESULTS}

Expt I. Retention of ${ }^{54} \mathrm{Mn}$ in the whole bird was always a small proportion of the dose, the overall mean being only $4.0 \%$. Of the total retained, a large proportion was present in the liver, the mean for all birds being $36 \%$, and there was a highly significant positive correlation between the amount in the liver and total retention, $r=0.706$.

Mean values for percentage retention of ${ }^{54} \mathrm{Mn}$ in the whole bird and liver, and liver contents as a percentage of that in the whole bird for the various treatment groups, are given in Table 2. There was no significant effect of sex on the retention of ${ }^{54} \mathrm{Mn}$ in hybrid layer birds (groups A v. B), nor was there any difference in retention between cockerels of hybrid broiler and hybrid layer birds (groups B v. C), and the proportion of the total found in the liver was similar in all three groups. Two-week-old birds (group D) retained significantly more ${ }^{54} \mathrm{Mn}(4.47 \%$ ) than 5 -week-old birds (group E, $2.83 \%$ ): the difference was less striking for the liver, giving rise to a significant difference in the proportion of total ${ }^{54} \mathrm{Mn}$ in the liver : $33.5 \%$ in 2-week-old birds and $28.9 \%$ in 5 -week-old birds.

The comparison made with 2 -week-old birds of fasting for $\mathrm{I} \frac{1}{2} \mathrm{~h}$ (group F) or $24 \mathrm{~h}$ (group $G$ ) before dosing gave no significant difference. The comparison made with 5 -week-old birds of killing them $4 \mathrm{~h}$ (group H) or $24 \mathrm{~h}$ (group I) after dosing showed significantly greater retention in those killed at $4 \mathrm{~h}(4.43 \%$ of dose in whole bird $)$ than in those killed at $24 \mathrm{~h}(2.83 \%)$; the difference was smaller for the liver $(\mathrm{I} \cdot 93 \% \mathrm{v}$. $\mathrm{I} \cdot \mathrm{IO} \%$ ) but still significant. The proportion in the liver of total ${ }^{54} \mathrm{Mn}$ retained was greater in birds killed $4 \mathrm{~h}$ after the dose $(44.5 \%)$ than in those killed $24 \mathrm{~h}$ after $(37.8 \%)$ but the difference did not reach significance. 
Expt 2. Mean values for the retention of ${ }^{54} \mathrm{Mn}$, given as the chloride orally in solution with different quantities of inactive $\mathrm{Mn}\left({ }^{55} \mathrm{Mn}\right)$, are given in Table 3. Standard errors of differences between means are given, differences being statistically significant when the difference between two means exceeds three times the SE of a difference.

Table 2. Expt I. Effects on retention of ${ }^{54} M n$ by the chick of sex and hybrid type, age, period of fasting before dosing and period between dosing and killing

\begin{tabular}{|c|c|c|c|}
\hline & & ${ }^{54} \mathrm{Mn}$ as & $f$ dose \\
\hline Group & $\begin{array}{l}\text { No. of } \\
\text { birds }\end{array}$ & Whole bird & Liver \\
\hline
\end{tabular}
A, layer hybrid $q$
B, layer hybrid $\hat{o}$
C, broiler hybrid $\delta$

$\begin{array}{rrrr}25 & 4.45 & 1 \cdot 56 & 36 \cdot 3 \\ 25 & 3.99 & 1 \cdot 36 & 34 \cdot 9 \\ 25 & 3.47 & 1 \cdot 35 & 37 \cdot 8 \\ & \pm 0.47 & \pm 0.22 & \pm 3 \cdot 18 \\ & \text { NS } & \text { NS } & \text { NS }\end{array}$
SE of difference between means
Statistical significance of
difference, $P$
D, 2-week-old
E, 5-week-old
E, 5-week-old
SE of difference between means
Statistical significance of
$2 \mathrm{I} \quad 4.47-\mathrm{I} \cdot 48$
I7 $\begin{array}{rrr}2.83 & 1 \cdot 10 & 33.2 \\ +0.49 & +0.22 & 37.8 \\ & +0.01 .14\end{array}$
$\leq 0.010 .0010$
$<0.05$
$F$, fasted $x \frac{1}{2} h$
$\mathrm{G}$, fasted $24 \mathrm{~h}$
$4 \cdot 47$
$\mathrm{I} \cdot 48$
$33 \cdot 2$
$3 \cdot 94 \quad \mathrm{I} \cdot 23-32 \cdot 5$
$\mathrm{SE}$ of difference between means
Statistical significance of
$\pm 0$.
$\pm 0.18$
$\pm 2 \cdot 36$
NS
$H$, killed $4 \mathrm{~h}$ after dose
I, killed $24 \mathrm{~h}$ after dose
NS NS
SE of difference between means Statistical significance of

$\begin{array}{rr}4.43 & 1.93 \\ 2.83 & 1.10 \\ \pm 0.55 & \pm 0.31 \\ <0.01 & <0.05\end{array}$
$44 \cdot 5$
$37 \cdot 8$
$\pm 4.55$ difference, $P$

NS, not significant.

Table 3. Expt 2. Effects on retention of ${ }^{54} M n$ by the chick of increasing the concentration of non-radioactive manganese given with the radioactive dose

$\begin{array}{ccccc}\begin{array}{c}\text { Amount of } \\ \begin{array}{c}\text { non-radioactive } \\ \text { Mn }(\mu \mathrm{g})\end{array}\end{array} & \begin{array}{c}\text { No. of } \\ \text { birds }\end{array} & \text { Whole bird } & \text { Liver } & \begin{array}{c}\text { Liver }{ }^{54} \mathrm{Mn} \text { as } \\ \% \text { of that in } \\ \text { whole bird }\end{array} \\ 0 & 5 & 2.52 & 1.18 & 46.9 \\ 250 & 5 & 2.46 & 1.02 & 41.3 \\ 625 & 5 & 2.33 & 0.96 & 40.6 \\ 1250 & 5 & 1.50 & 0.55 & 37.8 \\ \text { I } 875 & 5 & 1.26 & 0.46 & 36.8 \\ 2500 & 5 & 1.43 & 0.42 & 30.1 \\ 5000 & 5 & 1.02 & 0.27 & 26.3 \\ \text { SE of difference between means } & \pm 0.28 & \pm 0.13 & \pm 2.65 \\ \text { Statistical significance of } & <0.001 & <0.001 & <0.001 \\ \text { difference, } P\end{array}$

When the quantity of inactive Mn added to the dose was increased from 0 to $5000 \mu \mathrm{g}$ there was a highly significant decrease in total retention $(P<0.00 \mathrm{I})$. The rate of decrease tended to become less as the quantity of inactive Mn increased (see 
Fig. I). A similar picture was given by the mean values for retention in the liver but the latter effect was relatively greater, and hence the liver retention of ${ }^{54} \mathrm{Mn}$ declined from $46 \cdot 9 \%$ to $26 \cdot 3 \%$ of the total retention as the dose of inactive $\mathrm{Mn}$ increased from zero to $5000 \mu \mathrm{g}$.

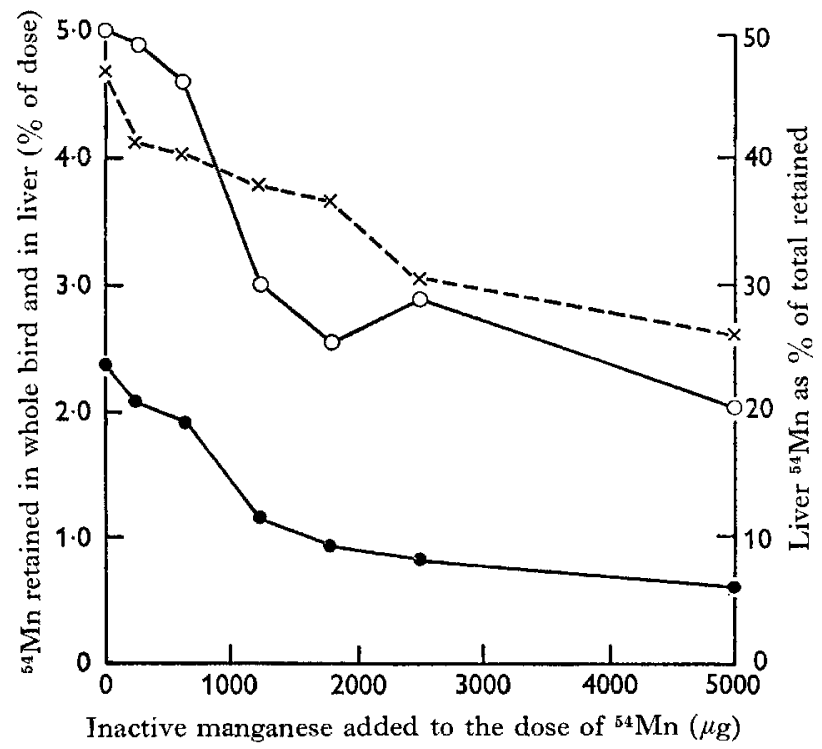

Fig. I. The effects on retention of ${ }^{54} \mathrm{Mn}$ by the chick of increasing the concentration of inactive manganese with a fixed dose of ${ }^{54} \mathrm{Mn}$. $\mathrm{O}-\mathrm{O}, \%$ of dose of ${ }^{54} \mathrm{Mn}$ retained in the whole bird; $-\%$ of dose of ${ }^{54} \mathrm{Mn}$ retained in the liver; $x---x$, liver ${ }^{54} \mathrm{Mn}$ as $\%$ of total retained.

\section{DISCUSSION}

In a study of ${ }^{54} \mathrm{Mn}$ retention in the laying bird, the proportions of a dose of ${ }^{54} \mathrm{Mn}$ found in droppings, liver and blood (Hill, 1965) suggested that Mn retention was very low. From the two experiments described here with chicks in which retention was determined by analysis of the whole bird, confirmation is provided of a very low retention, less than $5 \%$ of the dose. It should be noted also that these values were obtained in conditions most likely to favour absorption and retention: the birds had been given a low-Mn diet and the dose was given in solution with only a very small quantity of non-radioactive $\mathrm{Mn}(<0 \cdot \mathrm{I} \mu \mathrm{g})$.

In Expt I the more rapidly growing birds (broiler-type cockerels) were expected to retain a greater proportion of the dose than those growing more slowly (layer-type pullets); in fact in 2 - and 5-week-old birds mean retention was greater for the slowergrowing birds, but the difference did not reach statistical significance. The stage of growth had a marked effect on retention when the measure of difference was age; 2-week-old birds retained $58 \%$ more than 5 -week-old birds given the same dose. This result is particularly striking when it is recalled that during the further 3 weeks of growth from 2 to 5 weeks of age the birds continued to receive the low-Mn diet (4 $\mu \mathrm{g} \mathrm{Mn} / \mathrm{g})$.

From a comparison of retention of ${ }^{54} \mathrm{Mn}$ at 4 and $24 \mathrm{~h}$ after the dose it may be con- 
cluded that, even in these birds given a low-Mn diet, absorbed Mn was not efficiently retained; birds killed $24 \mathrm{~h}$ after the dose contained only about two-thirds $(64 \%)$ of the quantity found in birds killed $4 \mathrm{~h}$ after the dose. There was evidently a fairly large obligatory loss even in the face of an overall shortage of the element.

In a previous experiment (Hill, I965) the addition of $1000 \mu \mathrm{g}$ of non-radioactive $\mathrm{Mn}$ to a dose of ${ }^{54} \mathrm{Mn}$ decreased the proportion of the dose found in the liver but the decrease was small considering the large addition of Mn. Here in Expt 2 using chicks and a large range of additions of $\mathrm{Mn}$ to the dose of ${ }^{54} \mathrm{Mn}$, a similar result was obtained. When the amount of $\mathrm{Mn}$ present with a fixed dose of ${ }^{54} \mathrm{Mn}$ was increased from none $(0 \cdot \mathrm{I} \mu \mathrm{g})$ to $5000 \mu \mathrm{g}$, total body retention was reduced only from $2 \cdot 52 \%$ to $\mathrm{I} \cdot 02 \%$ of the dose of ${ }^{54} \mathrm{Mn}$, and, if it is assumed that radioactive and non-radioactive $\mathrm{Mn}$ are absorbed and retained equally, the total quantity of Mn retained increased strikingly from $0.0025 \mu \mathrm{g}$ with no added $\mathrm{Mn}$ to $5 \mathrm{I} \cdot 0 \mu \mathrm{g}$ with $5000 \mu \mathrm{g}$ added $\mathrm{Mn}$, a 2000 -fold increase. It appears that retention and probably absorption of $\mathrm{Mn}$ are influenced largely by the concentration of the element in solution in the gut over a very wide range of concentrations, an observation that argues in favour of a passive rather than an active transport process in the passage of Mn across the gut wall.

The efficient technical assistance of Mrs Ann Hosier is gratefully acknowledged. We also acknowledge assistance from the British Egg Marketing Board in defraying the cost of these experiments.

\section{REFERENCES}

Hill, R. (1965). Br. Y. Nutr. r9, I7I.

Hill, R. (1967). Br, F, Nutr. 21, 507. 